\title{
The enhancing effect of Acanthopanax sessiliflorus fruit extract on the antibacterial activity of porcine alveolar 3D4/31 macrophages via nuclear factor kappa $\mathrm{B} 1$ and lipid metabolism regulation
}

\author{
Eunmi Hwang1', Gye Won Kim², Ki Duk Song ${ }^{3}$, Hak-Kyo Lee, ${ }^{3, *}$ and Sung-Jo Kim,*
}

\author{
* Corresponding Authors: \\ Hak-Kyo Lee \\ Tel: +82-63-270-2548, Fax: +82-63-270-5937 \\ E-mail: breedlee@jbnu.ac.kr \\ Sung-jo Kim \\ Tel: +82-41-540-5571, Fax: +82-41-540-9538, \\ E-mail: sungjo@hoseo.edu
}

'Division of Cosmetics and Biotechnology, College of Life and Health Sciences, Hoseo University, Baebang, Asan 31499, Korea

2 Brewing Research Center, Academic Industry

Cooperation, Hankyong National University, Anseong 17579, Korea

Department of Animal Biotechnology, Chonbuk National University, Jeonju 54896, Korea

ORCID

Eunmi Hwang

https://orcid.org/0000-0001-8166-384X Gye Won Kim

https://orcid.org/0000-0001-5819-4520

Ki Duk Song

https://orcid.org/0000-0003-2827-0873

Hak-Kyo Lee

https://orcid.org/0000-0001-5387-4885

Sung-jo Kim

https://orcid.org/0000-0003-4590-3644

Submitted Nov 21, 2018; Revised Jan 19, 2019; Accepted Feb 21, 2019
Objective: The demands for measures to improve disease resistance and productivity of livestock are increasing, as most countries prohibit the addition of antibiotics to feed. This study therefore aimed to uncover functional feed additives to help enhance livestock immunity and disease resistance, using Acanthopanax sessiliflorus fruit extract (ASF).

Methods: ASF was extracted with $70 \% \mathrm{EtOH}$, and total polyphenolic and catechin contents were measured by the Folin-Ciocalteu and vanillin assay, respectively. The 3D4/31 porcine macrophage cells $(\mathrm{M} \Phi)$ were activated by phorbol 12-myristate 13-acetate (PMA), and cell survival and growth rate were measured with or without ASF treatment. Flow-cytometric analysis determined the lysosomal activity, reactive oxygen species levels (ROS), and cell cycle distribution. Nuclear factor kappa B (NF- $\kappa \mathrm{B}$ ) and superoxide dismutase (SOD) protein expression levels were quantified by western blotting and densitometry analysis. Quantitative polymerase chain reaction was applied to measure the lipid metabolism-related genes expression level. Lastly, the antibacterial activity of 3D4/31 MФ cells was evaluated by the colony forming unit assay.

Results: ASF upregulated the cell viability and growth rate of 3D4/31 MФ, with or without PMA activation. Moreover, lysosomal activity and intracellular ROS levels were increased after ASF exposure. In addition, the antioxidant enzyme SOD2 expression levels were proportionately increased with ROS levels. Both ASF and PMA treatment resulted in upregulation of NF- $\kappa$ B protein, tumor necrosis factor (TNF) a mRNA expression levels, lipid synthesis, and fatty acid oxidation metabolism. Interestingly, co-treatment of ASF with PMA resulted in recovery of NF- $\kappa \mathrm{B}, \mathrm{TNF} \alpha$, and lipid metabolism levels. Finally, ASF pretreatment enhanced the in vitro bactericidal activity of 3D4/31 MФ against Escherichia coli.

Conclusion: This study provides a novel insight into the regulation of NF- $\kappa \mathrm{B}$ activity and lipid metabolism in $M \Phi$, and we anticipate that ASF has the potential to be effective as a feed additive to enhance livestock immunity.

Keywords: Porcine; Feed Additives; Acanthopanax sessiliflorus; Macrophages; Nuclear Factor Kappa B (NF-kB); Immunity

\section{INTRODUCTION}

A common factor connecting maggots, alcohol, saliva, medicinal herbs, and amputation is that they have been employed as a method to resist infections by microorganisms, although most of these are folk remedies without scientifically proven effects. In recent days, maggot therapy has been found to effectively inhibit the growth of certain microorganisms and in the removal of dead skin cells [1]. Nonetheless, folk remedies have largely disappeared after the 1940s, since the advent of antibiotics eliminated concerns of progressing bacterial infections. The twenty-first century has seen the indiscriminate use of antibiotics in numerous 
fields including food manufacture, pharmaceutics, and farming, resulting in the production of millions of tons of antibiotics [2]. Furthermore, although antibiotic-resistant bacteria (ARB) were discovered in the 1960s, antibiotic usage has steadily increased, and currently, the ARB are a serious threat to public health. According to the Centers for Disease Control and Prevention (CDC), the annual mortality rates due to ARB have reached 23,000 in the United States (US), 25,000 in the European Union (EU), 38,000 in Thailand, and 58,000 in India $[2,3]$. As a solution to this problem, although efforts have been focused on developing new antibiotics, the outcomes have been unable to keep up with the continued increase of ARB [4].

The CDC has indicated that the primary cause of ARB is the inessential use of antibiotics in farming, being indiscriminately administered without a therapeutic purpose. Originally, antibiotics mixed in feed were provided to farms for preventing infectious diseases in livestock. However, once the growthpromoting effects of antibiotics were identified, the use of livestock antibiotics increased exponentially. Presently, it constitutes over $50 \%$ of the total antibiotics usage in most advanced countries, and accounting at over $80 \%$ in the US [5]. ARB in livestock can be transmitted to humans through food; furthermore, over $90 \%$ of livestock fed antibiotics are excreted, resulting in environmental pollution and ARB generation [3]. Hence, this study was undertaken to focus and investigate natural materials that improve the immunity and disease resistance of livestock, thereby laying the groundwork for the development of functional feed additives that will reduce indiscriminate antibiotic usage.

The mammalian immune system comprises of innate and adaptive immunity. Briefly, the porcine alveolar 3D4/31 macrophages $(M \Phi)$ are the innate immune cells that contribute to the lung immunity by removing the sources of infection, thereby performing a crucial function in disease resistance in livestock, especially in respiratory infectious diseases such as the porcine respiratory disease complex (PRDC) [6]. Nonetheless, no studies have actively investigated plant materials that may regulate livestock alveolar $M \Phi$ function. The $M \Phi$ are activated in the presence of cytokines or when toll-like receptors (TLR) recognize the endotoxin. The $М \Phi$ activation first induces acute morphological changes [7], at the same time enhancing the phagocytosis, inflammatory signaling, and lipid metabolism. These metabolic changes are controlled by nuclear factor kappa B (NF-kB), which is a transcription factor that induces the expression of proinflammatory genes such as tumor necrosis factor a (TNF $\alpha)$, interleukin (IL)-1 $\beta$, IL-6, and IL-8 [8]. The enhanced lipid metabolism increases fatty acid synthesis, and fatty acid oxidation (FAO) a crucial factor for inducing alveolar M $\Phi$ activation $[9,10]$. Subsequently, the increased production of reactive nitrogen species (RNS) and reactive oxygen species
(ROS) contribute to phagocytosis [11]. These metabolic changes enhance phagocytosis and help in removing the infection sources; however, the proliferation of activated $\mathrm{M} \Phi$ is downregulated by cell cycle arrest, followed by rapid apoptosis [12].

Upregulated NF- $\kappa \mathrm{B}$ signaling and lipid metabolism are essential for $\mathrm{M} \Phi$ activation, although excessive enhancement may result in hyperinflammatory response and apoptosis [13]. Thus, for the effective improvement of innate immunity based on alveolar $\mathrm{M} \Phi$, the phagocytic activity needs to be enhanced, while suppressing the excessive lipid metabolism and hyperinflammatory response. In this study, we aimed to discover natural materials that enhance phagocytic activity while preventing cell death and inflammatory response. Acanthopanax sessiliflorus (A. sessiliflorus) grows in Korea, China, and Japan; the roots and rinds of Acanthopanax species have long been used in traditional medicines. In the present day, this substance provides health supplements due to its scientifically proven diverse effects on immunity; however, very few researches have studied the fruits $[14,15]$, and there is no study yet on the effect of $A$. sessiliflorus fruits on porcine alveolar $M \Phi$. Therefore, this study was undertaken to verify the effect of A. sessiliflorus fruit extract (ASF) on 3D4/31 MФ, and confirm that exposure to ASF increases the survival rate and phagocytic activity. As the first attempt at investigating the effects of ASF on porcine $M \Phi$, the findings of this study suggest new strategies and possibilities regarding the development of natural feed additive materials that are useful in enhancing porcine immunity, thereby reducing the use of antibiotics.

\section{MATERIALS AND METHODS}

\section{Preparation of $A$. sessiliflorus fruit extract}

The fruits of A. sessiliflorus were obtained in November 2014 from the Jeongseon Myungju Co.Ltd., Jeongseon, Korea. The air-dried fruits of $A$. sessiliflorus (100 g) were powdered and extracted three times for $24 \mathrm{~h}$ with $1 \mathrm{~L}$ of aqueous $70 \% \mathrm{EtOH}$ at room temperature. The ASF was used after concentration in vacuo.

\section{Measurement of total phenolic and catechin contents}

Total phenolic and catechin contents of ASF were measured by the Folin-Ciocalteu method and vanillin-catechin assay, respectively, as described previously [16]. The results are expressed in milligram of gallic acid or catechin equivalents per gram (dried weight) of ASF.

\section{Cell culture and reagents}

Porcine 3D4/31 MФ (ATCC-CRL-2844) were purchased from the American Type Culture Collection (ATCC, Manassas, VA, USA). The cells were cultured at $37^{\circ} \mathrm{C}$ in a $\mathrm{CO}_{2}$ incubator (Thermo Fisher Scientific, Waltham, MA, USA; 95\% air and $5 \% \mathrm{CO}_{2}$ ). The Roswell Park Memorial Institute 1640 medium 
(RPMI 1640; Corning, NY, USA) supplemented with 10\% $(\mathrm{v} / \mathrm{v})$ thermally inactivated fetal bovine serum (Welgene, Gyeongsan, Korea) and 1\% (v/v) of a penicillin-streptomycin solution (Welgene, Korea) was used for cell cultures.

Cell viability and growth curve analysis

To assess the cell viability, 3D4/31 MФ $\left(5 \times 10^{3}\right.$ cells/well in $100 \mu \mathrm{L}$ of media) were seeded in a 96-well cell culture plate (SPL Life Sciences, Pocheon, Korea). The cells were incubated for $12 \mathrm{~h}$ and treated with vehicle (distilled water; DW) or ASF $(1.2,12$, and $120 \mu \mathrm{g} / \mathrm{mL})$ for $24 \mathrm{~h}$. Phorbol 12-myristate 13-acetate (PMA, 2 nM; Sigma-Aldrich, St. Louis, MO, USA) was then added for activation of $M \Phi$. The final concentration of 10\% (v/v) WST-1 reagent (EZ Cytox Cell Viability Assay Kit; DoGenBio, Seoul, Korea) was administered, followed by incubation for $2 \mathrm{~h}$. The cell viability (optical density [OD] at $450 \mathrm{~nm}$ ) was measured on a microplate reader (Sunrise, Tecan, Männedorf, Switzerland) and normalized to the vehicle (without PMA). For the growth curve analysis, 3D4/31 MФ $\left(5 \times 10^{4}\right.$ cells) were seeded in a $60 \mathrm{~mm}$ cell culture dish (SPL Life Sciences) and incubated for $12 \mathrm{~h}$. ASF $(120 \mu \mathrm{g} / \mathrm{mL})$ was added to the cells and further incubated either with or without $2 \mathrm{nM}$ PMA, and vehicle (DW). The medium was replenished and cells were treated again every $24 \mathrm{~h}$, for 3 days. Growth curve was assessed by subjecting the cells to staining with $0.4 \%(\mathrm{w} / \mathrm{v})$ trypan blue dye (Thermo Fisher Scientific, USA) and counting the cell number on a hemocytometer, for 3 days at every $24 \mathrm{~h}$ interval.

\section{Cell cycle analysis}

3D4/31 MФ $\left(10^{6}\right.$ cells $)$ were seeded in a $60 \mathrm{~mm}$ cell culture dish and incubated for $12 \mathrm{~h}$. The cells were treated with ASF $(120 \mu \mathrm{g} / \mathrm{mL})$ with or without PMA $(2 \mathrm{nM})$ for $24 \mathrm{~h}$, harvested, washed once in phosphate-buffered saline (PBS, pH 7.4), and resuspended in ice-cold ethanol, followed by $1 \mathrm{~h}$ incubation at $-80^{\circ} \mathrm{C}$ for fixing and permeabilization. The fixed cells were again washed with PBS once, after which $175 \mu \mathrm{L}$ of PBS with $5 \mu \mathrm{L}$ of $10 \mathrm{mg} / \mathrm{mL}$ RNase A (R6513; Sigma-Aldrich, USA) was added and incubated for $30 \mathrm{~min}$ at $25^{\circ} \mathrm{C}$, followed by staining with $500 \mu \mathrm{g} / \mathrm{mL}$ propidium iodide (PI; P-4170, SigmaAldrich, USA) for $10 \mathrm{~min}$ at $4^{\circ} \mathrm{C}$ in the dark. PI fluorescence intensity (cell cycle progression) was measured using the Guava EasyCyte (Millipore, Temecula, CA, USA) and FlowJo, version 10.0.7.2 (TreeStar, Ashland, OR, USA).

\section{Flow-cytometric analysis}

$3 \mathrm{D} 4 / 31 \mathrm{M} \Phi\left(10^{6}\right.$ cells) were seeded in a $60 \mathrm{~mm}$ cell culture dish and incubated for $12 \mathrm{~h}$. The cells were treated with ASF $(120 \mu \mathrm{g} / \mathrm{mL})$ with or without PMA $(2 \mathrm{nM})$ for $12 \mathrm{~h}$. To measure the autophagic activity, the acidic vesicular organelle indicator acridine orange (AO; Sigma-Aldrich, USA) was administered at a final concentration of $1 \mu \mathrm{g} / \mathrm{mL}$ and incubated for $30 \mathrm{~min}$.
The treated cells were harvested and washed twice with PBS. The 3D4/31 MФ ROS levels were measured using the ROS indicator dichlorofluorescein diacetate (DCFDA, 35845, Sigma-Aldrich, USA). DCFDA was administered at a final concentration of $10 \mu \mathrm{M}$, followed by incubation for $30 \mathrm{~min}$. The cells were harvested and washed once with PBS. Autophagic activity and ROS levels were then measured by Guava EasyCyte. AO-positive cells and DCF-MFI (median fluorescence intensity) were evaluated in the FlowJo software, version 10.0.7.2.

\section{Western blot analysis}

To measure the protein expression levels of NF- $\kappa \mathrm{B} 1$ and superoxide dismutase 2 (SOD2) in 3D4/31 M was performed as described previously [16]. Briefly, total protein samples were extracted from 3D4/31 M $\Phi$ treated with ASF $(120 \mu \mathrm{g} / \mathrm{mL})$ with or without PMA $(2 \mathrm{nM})$ for $12 \mathrm{~h}$; 50 $\mu \mathrm{g}$ of protein was loaded per lane on an electrophoretic gel. Resolved proteins were then probed with anti-NF- $\kappa B 1$ (Santa Cruz Biotechnology, Santa Cruz, CA, USA), anti-SOD2 (Cusabio Technology, Houston, TX, USA), and anti- $\beta$-actin antibodies (Santa Cruz Biotechnology, USA). Relative protein expression levels were determined by densitometric analysis in ImageJ. At least three separate experiments were conducted for each protein.

\section{Real-time polymerase chain reaction}

Real-time-polymerase chain reaction (RT-PCR) was carried out as described before [17]. Briefly, 3D4/31 MФ (10 cells) were seeded in a $60 \mathrm{~mm}$ dish and incubated for $12 \mathrm{~h}$. The cells were treated with ASF $(120 \mu \mathrm{g} / \mathrm{mL})$ with or without PMA $(2 \mathrm{nM})$ for $24 \mathrm{~h}$. Total RNA was isolated using the TRIzol Reagent (Thermo Fisher Scientific, USA), and complementary DNA (cDNA) was synthesized by means of Moloney murine leukemia virus reverse transcriptase (Enzynomics, Daejeon, Korea). Next, 10 ng of cDNA was used for RT-PCR to determine the mRNA expression levels. Primer sequences are described in Table 1. Relative mRNA expression levels were analyzed by the $2^{-\Delta \Delta \mathrm{Ct}}$ method.

\section{In vitro bacterial killing assay (colony-forming unit assay)}

3D4/31 MФ were treated with ASF $(120 \mu \mathrm{g} / \mathrm{mL})$ or vehicle (DW) for 24 h. Escherichia coli (E. coli) DH5a was cultured in the Luria-Bertani (LB) medium (Becton Dickinson, Franklin Lakes, NJ, USA) at $37^{\circ} \mathrm{C}$ and $200 \mathrm{rpm}$ in a shaking incubator for $12 \mathrm{~h}$, with additional incubation in fresh medium for 90 min. 3D4/31 MФ and E. coli DH5a were harvested and washed twice with ice-cold Hank's balanced salt solution (HBSS). $3 \mathrm{D} 4 / 31 \mathrm{M} \Phi\left(10^{6}\right.$ cells $)$ and E. coli DH5 $\alpha\left(2.5 \times 10^{6}\right.$ cells $)$ were mixed in $1 \mathrm{~mL}$ of HBSS supplemented with $5 \%(\mathrm{w} / \mathrm{w})$ porcine serum, followed by incubation at $37^{\circ} \mathrm{C}$ and $170 \mathrm{rpm}$ in 
Table 1. Primer sequences for $3 \mathrm{D} 4 / 31 \mathrm{M} \Phi$

\begin{tabular}{|c|c|}
\hline Gene & Sequences ( $\left(5^{\prime}\right.$ to $\left.3^{\prime}\right)$ \\
\hline $\begin{array}{l}\text { TNFa } \\
\quad \text { (tumor necrosis factor alpha) }\end{array}$ & $\begin{array}{l}\text { F: CGTTGTAGCCAATGTCA } \\
\text { R:TAGGAGACGGCGATGC }\end{array}$ \\
\hline $\begin{array}{l}\text { PPAR } \\
\quad \text { (peroxisome proliferator-activated receptor) }\end{array}$ & $\begin{array}{l}\text { F: TTGAACGACCAGGT CACGCT } \\
\text { R: GGAACTCGCGCGTGATGAAG }\end{array}$ \\
\hline $\begin{array}{l}\text { FASN } \\
\text { (fatty acid synthase) }\end{array}$ & $\begin{array}{l}\text { F: GTGGAGGTGCGCCAGATACT } \\
\text { R: CCTCGTGGGATGTGGGAGTC }\end{array}$ \\
\hline $\begin{array}{l}\text { GAPDH } \\
\text { (glyceraldehyde 3-phosphate dehydrogenase) }\end{array}$ & $\begin{array}{l}\text { F: GTCGGAGTGAACGGATTTGGC } \\
\text { R:ACTGTGCCGTGGAATTTGCC }\end{array}$ \\
\hline $\begin{array}{l}\text { CPT1A } \\
\text { (carnitine palmitoyltransferase 1a) }\end{array}$ & $\begin{array}{l}\text { F: CAAGATAGCGGCCGAAAAGC } \\
\text { R: GATAATCGCCACGGCTCAGA }\end{array}$ \\
\hline $\begin{array}{l}\text { CPT1B } \\
\quad \text { (carnitine palmitoyltransferase } 1 \mathrm{~b})\end{array}$ & $\begin{array}{l}\text { F: CCACTATGACCCGGAAGACG } \\
\text { R:TTGAACGCGATGAGGGTGAA }\end{array}$ \\
\hline $\begin{array}{l}A C A D V L \\
\text { (acyl-CoA dehydrogenase, very long chain) }\end{array}$ & $\begin{array}{l}\text { F: GCGGTGAATCATGCTGCTAA } \\
\text { R: GTGGATCCCTGGTCCATGTT }\end{array}$ \\
\hline $\begin{array}{l}\text { ACAA1 } \\
\qquad \text { (acetyl-CoA acyltransferase 1) }\end{array}$ & $\begin{array}{l}\text { F: TCGCCCAGTTTCTGAGTGAC } \\
\text { R: CCACAAGCCATGCCAATGTC }\end{array}$ \\
\hline $\begin{array}{l}\text { ACAA2 } \\
\quad \text { (acetyl-CoA acyltransferase 2) }\end{array}$ & $\begin{array}{l}\text { F:TCGTGGGCTATTTTGCGTCT } \\
\text { R:TCCTGCTTTCTTCAGTGCCC }\end{array}$ \\
\hline $\begin{array}{l}\text { CTS } \\
\text { (citrate synthase) }\end{array}$ & $\begin{array}{l}\text { F: GGGCACTGGGTGTATTAGCA } \\
\text { R:TCATGGACTTGGGCCTCTCT }\end{array}$ \\
\hline $\begin{array}{l}\text { IDH3 } \\
\text { (isocitrate dehydrogenase 3) }\end{array}$ & $\begin{array}{l}\text { F: CGCTGCAAAGATTGAGACCG } \\
\text { R: TCTGAGCATTTTGCGTTGCC }\end{array}$ \\
\hline $\begin{array}{l}\text { MDH1 } \\
\text { (malate dehydrogenase1) }\end{array}$ & $\begin{array}{l}\text { F: TGGTGTTCCTGATGATCTGCTC } \\
\text { R:ACCCTTCAGCTCTGCAACAA }\end{array}$ \\
\hline
\end{tabular}

$M \Phi$, macrophage; $F$, forward; $R$, reverse.

a shaking incubator for $2 \mathrm{~h}$. For the MФ killing assay, $100 \mu \mathrm{L}$ of the cell mixture was collected at 15 min intervals, starting at $1 \mathrm{~h}$ after the incubation initiation. The collected cell mixtures were centrifuged at $1,500 \mathrm{rpm}$ (213.81 $\mathrm{g}$-forces) and $4^{\circ} \mathrm{C}$ for $1 \mathrm{~min}$, washed with HBSS two times, and resuspended in $100 \mu \mathrm{L}$ of DW followed by $5 \mathrm{~min}$ incubation at $25^{\circ} \mathrm{C}$ for disruption of $M \Phi$. These disrupted cell mixtures were centrifuged at $1,500 \mathrm{rpm}$ (213.81 g-forces) and $4^{\circ} \mathrm{C}$ for $5 \mathrm{~min}$; $10 \mu \mathrm{L}$ of the resultant supernatant was mixed with $90 \mu \mathrm{L}$ of DW and spread on LB Agar plates. Colony-forming units (CFUs) were quantified after incubation for $12 \mathrm{~h}$ at $37^{\circ} \mathrm{C}$. Representative LB Agar plate images were acquired with iPhone 6 (Apple Inc, Cupertino, CA, USA) and processed in Photoshop CC 2017 software (Adobe Systems, San Jose, CA, USA).

\section{Statistical analysis}

All the data are obtained from at least three independent experiments. The data are expressed as the mean \pm standard deviation. Analysis was performed by GraphPad PRISM 7 (GraphPad Software, San Diego, CA, USA) and Microsoft Excel (Office 365, Microsoft, Redmond, WA, USA). Twotailed Student's $t$-test was used for measuring the p-value and significance of the data. Data are considered statistically significant when the $\mathrm{p}$-value is $<0.05$.

\section{RESULTS}

Total phenolics and catechin contents in A. sessiliflorus fruit extract

For identifying the active ingredient of ASF, we determined the total phenolic and catechin contents. Our results showed that $1 \mathrm{~g}$ (dried weigh) of ASF contains $804.45 \pm 16.47 \mathrm{mg}$ of total phenolics and $5.36 \pm 0.33 \mathrm{mg}$ of catechin (Table 2). Plants produce unique secondary metabolites, depending on numerous surrounding factors, for adaptation or resistance to the environmental conditions [18]. Most of the polyphenols are secondary metabolites derived from natural plants; polyphenols are compounds with two or more phenol rings in their molecule, and are known to exert an antioxidant effect [19]. Furthermore, some polyphenols have anticancer, anti-inflammatory, and other beneficial biologic effects [20]. The wellknown polyphenol catechin is composed of two benzene rings with a dihydropyran heterocycle. Several types of catechin enhance the phagocytosis activity of $\mathrm{M} \Phi$ by controlling the cell death signaling [21]. Green tea leaves contain approximately $205.4 \pm 5.5 \mathrm{mg} / \mathrm{g}$ total catechin [22]; this it 40 -fold higher than that in ASF. However, Panax ginseng root, known as an effective immunostimulant, is reported to contain total phenolics at $32.4 \pm 0.1 \mu \mathrm{g} / \mathrm{g}$, indicating that ASF contains approximately 24,800-fold more phenolics than Panax ginseng [23]. Our results therefore indicate that the phagocytosisenhancing effect of ASF may not be caused by catechin, but may due to the large amounts of other polyphenols present.

\section{A. sessiliflorus fruit extract upregulates the cell survival rate}

Activated $M \Phi$ have reduced viability and proliferation, and eventually undergo apoptosis [12]. Therefore, upregulation of viability and proliferation is important for enhancing $M \Phi$ activity. We evaluated whether ASF upregulated the viability and proliferation of 3D4/31 M $\Phi$, with or without PMA (Figure 1A, 1B). We observed that cell viability of ASF-treated 3D4/31 MФ increased in a dose-dependent manner, with maximum increase of $11.73 \% \pm 2.02 \%$ at $120 \mu \mathrm{g} / \mathrm{mL}$. Addition of PMA reduced the viability by $5.53 \% \pm 1.13 \%$ relative to the vehicle, and ASF upregulated it up to $21.56 \% \pm 0.63 \%$ (Figure $1 \mathrm{~A}, \mathrm{p}<0.001)$. In addition, ASF $(120 \mu \mathrm{g} / \mathrm{mL}, 72 \mathrm{~h}$ treatment duration) upregulated the $3 \mathrm{D} 4 / 31 \mathrm{M} \Phi$ proliferation rate up

Table 2. Total phenolic and catechin content in Acanthopanax sessiliflorus fruit extract

\begin{tabular}{lc}
\hline Items & \\
\hline Dried weight $(\mathrm{mg} / \mathrm{mL})$ & $119 \pm 0.001$ \\
Catechin $(\mathrm{mg} / \mathrm{g})$ & $5.36 \pm 0.33$ \\
Total phenolic $(\mathrm{mg} / \mathrm{g})$ & $804.45 \pm 16.47$ \\
\hline
\end{tabular}



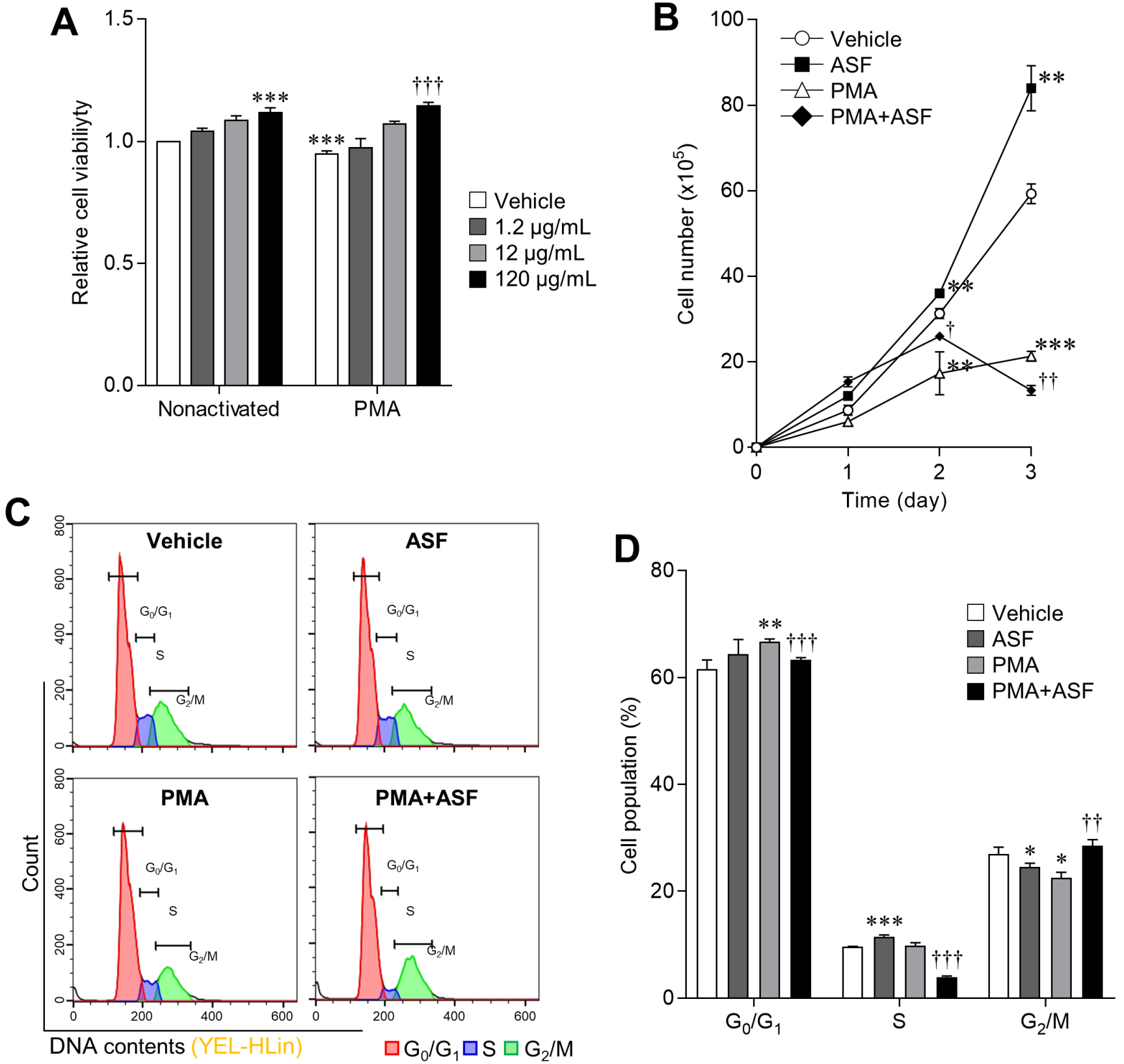

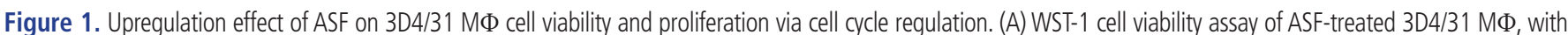

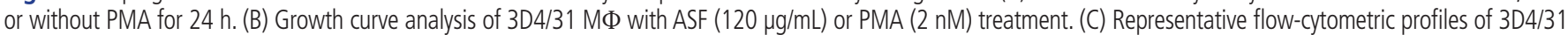

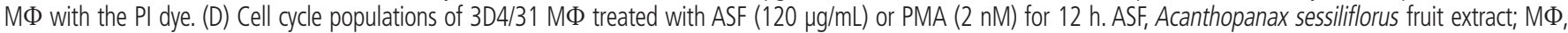
macrophage; PMA, phorbol 12-myristate 13-acetate; PI, propidium iodide. Data represent the mean \pm standard deviation $(n=3) ;{ }^{*} p<0.01,{ }^{* *} p<0.01,{ }^{* * *} p<0.001 \mathrm{vs}$ vehicle; ${ }^{\dagger} p<0.01,{ }^{+\dagger} p<0.01,{ }^{+\dagger \dagger} p<0.01$ vs PMA treated group.

to $41.57 \% \pm 8.92 \%$ (day $3, \mathrm{p}<0.01$ ), and PMA treatment downregulated it by $64.04 \% \pm 1.95 \%$ (day $3, \mathrm{p}<0.001$ ), compared to the vehicle control. Furthermore, ASF treatment inhibits the PMA-induced antiproliferative effect up to $155.56 \% \pm 13.32 \%$ (vs PMA, $\mathrm{p}<0.001$ ) on day 1 , and $50 \%$ on day 2 (vs group PMA, $\mathrm{p}<0.01$, Figure 1B).

$\mathrm{M} \Phi$ are the key and loyal soldiers of innate immunity; bacteria-induced activation reduces their proliferation and compromises their survival as they focus on phagocytosis
[24]. ASF increased the survival rate of both non-activated and PMA activated 3D4/31 MФ. Increased cell viability indicates two possible effects of ASF: on cell proliferation (number of mitochondria) or on mitochondrial activity [25]. Besides, the upregulation of mitochondrial activity can further contribute to cell proliferation. This increase in survival rates indicates that ASF is able to extend the M $\Phi$ life, enabling them to remove more bacteria. 
Table 3. Cell cycle population of ASF treated 3D4/31 macrophage

\begin{tabular}{lcccc}
\hline Items & Vehicle (\%) & ASF (\%) & PMA (\%) & PMA+ASF (\%) \\
\hline $\mathrm{G}_{\mathrm{O}} / \mathrm{G}_{1}$ & $61.60 \pm 1.68$ & $64.33 \pm 2.77$ & $66.73 \pm 0.46^{\mathrm{b}}$ & $63.27 \pm 0.45^{\mathrm{e}}$ \\
$\mathrm{S}$ & $9.60 \pm 0.10$ & $11.50 \pm 0.35^{\mathrm{c}}$ & $9.83 \pm 0.56$ & $3.94 \pm 0.18^{\mathrm{e}}$ \\
$\mathrm{G}_{2} / \mathrm{M}$ & $26.93 \pm 1.30$ & $24.57 \pm 0.68^{\mathrm{a}}$ & $22.53 \pm 1.03^{\mathrm{a}}$ & $28.50 \pm 1.14^{\mathrm{d}}$ \\
\hline
\end{tabular}

Data expressed as mean \pm standard deviation value of three replicates.

ASF, Acanthopanax sessiliflorus fruit extract; PMA, phorbol 12-myristate 13-acetate.

Statistical significance was assessed with respect to the vehicle or PMA treated sample in the same phase (vs vehicle: ${ }^{a} p<0.05,{ }^{b} p<0.01,{ }^{c} p<0.001 ;$ vs PMA treated: ${ }^{d}$ $\left.p<0.01,{ }^{e} p<0.001\right)$

\section{A. sessiliflorus fruit extract inhibits phorbol}

12-myristate 13-acetate-induced cell cycle arrest

$\mathrm{M} \Phi$ activation triggers cell cycle inhibition, consequent to a suppressed proliferation rate [24]. However, exposure to ASF upregulates the viability and proliferation of activated 3D4/31 $\mathrm{M} \Phi$ (Figure 1A and 1B). To determine whether ASF has an effect on cell cycle regulation-based proliferation, we analyzed the cell cycle by PI staining, and confirmed that ASF inhibits the PMA-induced cell cycle arrest in 3D4/31 MФ (Figure 1C and 1D, and Table 3). PMA treatment induces the cell cycle arrest in the $G_{0} / G_{1}$ phases; the proportion of PMA-treated cells in the $G_{0} / G_{1}$ phases increased up to $8.33 \% \pm$ $0.75 \%$ (vs vehicle, $\mathrm{p}<0.01$ ), whereas ASF reduced this increase to $3.78 \% \pm 0.68 \%$ (vs PMA, $\mathrm{p}<0.001$ ). In addition, PMA treatment results in a decreased proportion of cells in the $G_{2} / M$ phases by $16.34 \% \pm 3.81 \%$ (vs vehicle $\mathrm{p}<0.05$ ), and exposure to ASF increased this proportion up to $26.48 \% \pm 5.01 \%$ (vs PMA, $\mathrm{p}<0.01$ ). However, in the absence of PMA, ASF induces cell cycle arrest in the $G_{0} / G_{1}$ phases. Cell cycle regulation depends on the activity of cyclin-dependent kinases (CDKs) and Cyclins. $M \Phi$ activation reduces proliferation via the regulation of cyclin D1 and p21 expression. Cyclin D1 is downregulated by $M \Phi$ activation, resulting in downregulation of the $\mathrm{G} 1$ phase [26], upregulation of $\mathrm{p} 21$, and inhibition of the binding of cyclin E to CDK2, followed by inhibition of cell cycle progression from $G_{1}$ to $S$ phase and subsequent apoptosis; however, cell cycle arrest by interferon $\gamma$ suppresses the apoptosis [12]. Thus, the cell cycle arrest in $М \Phi$ may lower or increase the cell survival rate, depending on the induction method. Our results indicate that ASF upregulates the cell survival rates through different cell cycle-regulatory actions in nonactivated and activated 3D4/31 MФ.

\section{A. sessiliflorus fruit extract upregulates lysosomal activity and reactive oxygen species production} The progression of phagocytosis involves several steps, including ingestion of microbes and digestion of ingested microbes by the formation of phagolysosomes [27]. Digestion is achieved by a lysosome that contains a digestive enzyme with high levels of RNS and ROS. Hence, lysosomal activities play an important role in phagocytosis [28]. In this study, we confirmed that ASF and PMA treatment upregulate the lysosomal activity in $3 \mathrm{D} 4 / 31 \mathrm{M} \Phi$ by $60.76 \% \pm 30.67 \%(\mathrm{p}<0.05)$ and $85.73 \% \pm$ $18.76 \%(\mathrm{p}<0.01)$, respectively, relative to the vehicle (Figure 2A, 2B; Q1+Q2). ROS levels were also increased up to $18.36 \%$ $\pm 4.35 \%$ by ASF treatment, and $58.38 \% \pm 3.12 \%$ by PMA. Moreover, cotreatment with ASF-PMA upregulated the lysosomal activity and ROS levels up to $172.63 \% \pm 39.61 \%$ and $104.55 \%$ $\pm 3.95 \%$, respectively, in comparison with the vehicle.

In normal tissue cells, ROS are mainly produced by mitochondrial metabolism; low levels of ROS play various signaling roles, whereas high concentrations are known to imduce inflammation and apoptosis in cells [29]. Most plant-based research is therefore aimed at reducing ROS levels to promote health [30]. However, ROS production is essential for innate immunity, as represented by bacterial phagocytosis. Activation of MФ causes mitochondria to migrate into phagosomes and subsequent mitochondrial ROS (mROS) production. Although cellular ROS may be cytotoxic, the increase of mROS in $M \Phi$ is essential for phagocytosis [31]. Hence, the ROS-inducing effect of ASF in 3D4/31 MФ may also have a positive influence on phagocytosis. In addition, ASF increases the survival rate and lysosomal activity of 3D4/31 MФ. Taken together, these results indicate that ASF effectively increases the phagocytic activity of 3D4/31 MФ.

\section{A. sessiliflorus fruit extract regulates $\mathrm{M} \Phi$ activation and inflammatory signaling}

Since ASF treatment results in upregulation of the cell survival rate and ROS levels in activated 3D4/31 MФ, we next evaluated the expression levels of transcription factor NF- $\kappa B 1$ (as an $\mathrm{M} \Phi$ activation and inflammation marker) and SOD2 (a key antioxidant enzyme of ROS redox signaling) [32]. We observed that relative to the vehicle, NF- $\kappa \mathrm{B} 1$ expression levels of 3D4/31 MФ increased by up to $65.05 \% \pm 7.42 \%$ after ASF exposure, and $114.94 \% \pm 19.36 \%$ after PMA treatment ( $\mathrm{p}<$ $0.001)$. However, ASF treatment inhibited the PMA-induced $\mathrm{NF}-\kappa \mathrm{B} 1$ expression by $34.73 \% \pm 6.23 \%(\mathrm{p}<0.05)$. Furthermore, SOD2 expression levels were increased by up to $89.4 \% \pm 10.74 \%$ $(\mathrm{p}<0.001)$ after ASF treatment, 249.30\% $\pm 72.42 \%(\mathrm{p}<0.01)$ after PMA treatment, and $325.45 \% \pm 99.35 \%(\mathrm{p}<0.01)$ by ASFPMA cotreatment (Figure 3A, 3B), as compared to vehicle control.

In mammalian cells, ROS are mainly produced by the mi- 
A

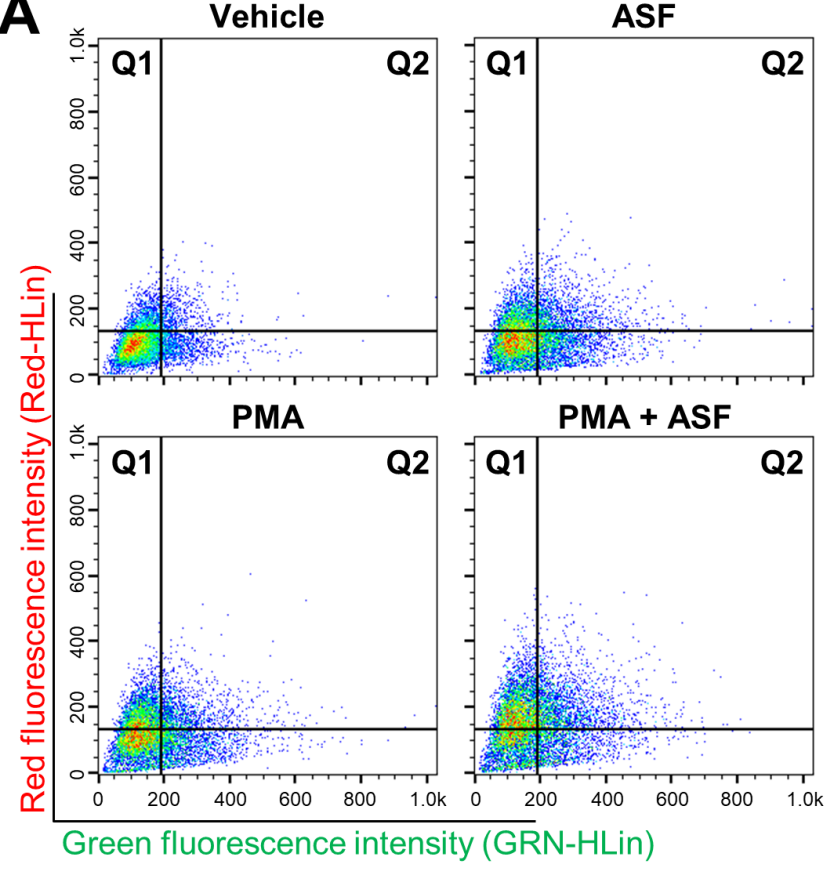

C

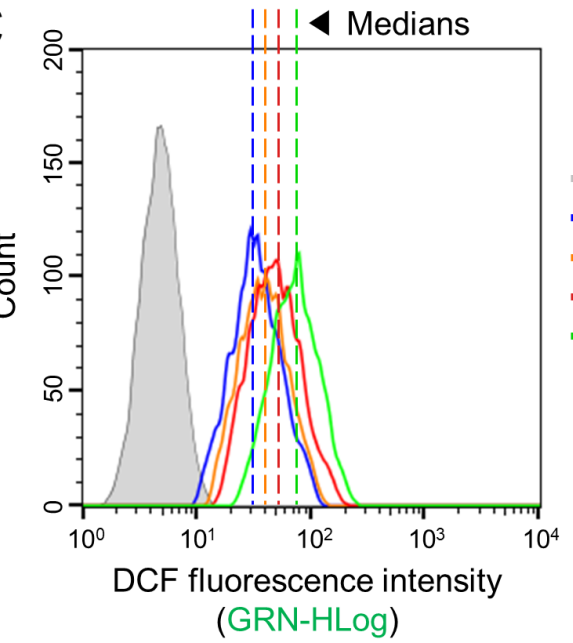

- Control

Vehicle

ASF

- PMA

PMA+ASF

B

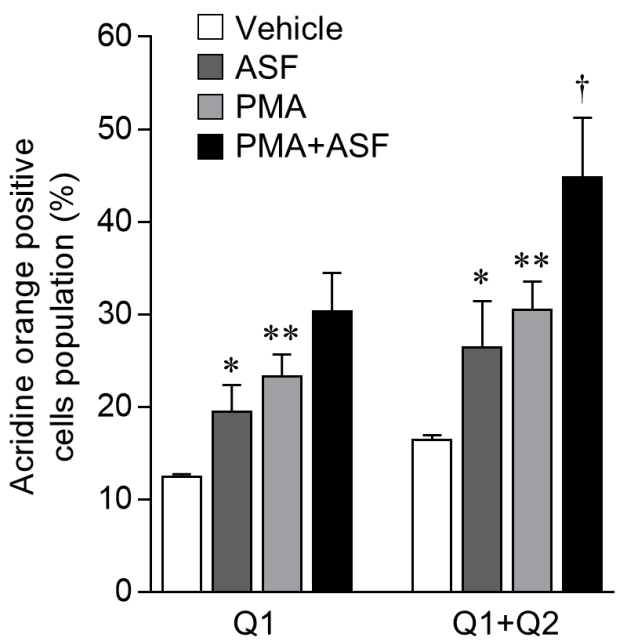

D

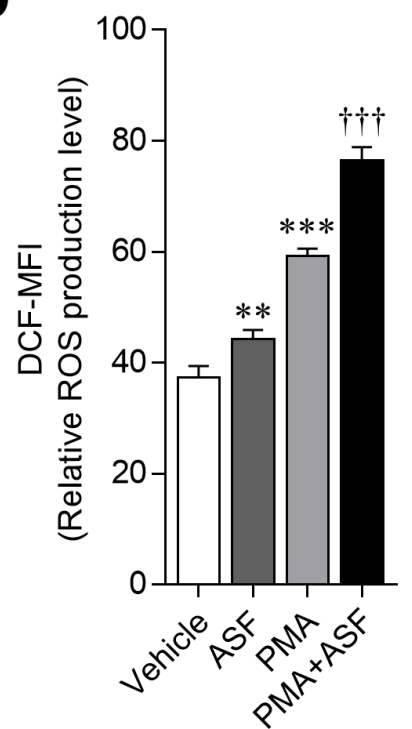

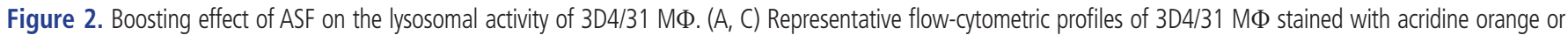
the DCFDA dye. (B) Acridine orange-positive cell (Q1 and Q2) population of 3D4/31 MФ treated with ASF or PMA for $12 \mathrm{~h}$. (D) Relative ROS production levels (DCF-MFI) of

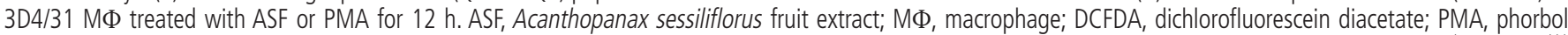
12-myristate 13-acetate; ROS, reactive oxygen species. Data represent the mean \pm standard deviation $(n=3) ;{ }^{*} p<0.01,{ }^{* *} p<0.01,{ }^{* * *} p<0.001$ vs vehicle; ${ }^{\dagger} p<0.01$, ${ }^{t+\dagger}$ $\mathrm{p}<0.01$ vs PMA treated group.

tochondrial electron transport, and are completely neutralized by SOD and other antioxidant enzymes and molecules. SOD is the most powerful antioxidant enzyme in our body, and is further classified as SOD1, 2, and 3, depending on the iron atom and its location. SOD2 (MnSOD) acts in the mitochondria [33], and therefore increased SOD2 expression suggests that upregulated ROS levels induced by ASF may be due to the formation of mROS, which are required for phagocytic activity [31]. Moreover, ASF induces the NF-kB1 expression but inhibits the same when $\mathrm{M} \Phi$ are activated by PMA.
In addition, NF- $\kappa \mathrm{B}$ and TNFa serve as positive feedback mediators to induce the expression of each other [34]. We confirmed a similar expression pattern of TNFa mRNA to NF- $\kappa B 1 ;$ PMA treatment increased the TNFa mRNA expression up to $151.72 \% \pm 6.02 \%$ (vs vehicle, $\mathrm{p}<0.001$ ), and ASF reduced it by $36.23 \% \pm 13.11 \%$ (vs PMA, $p<0.01$, Figure $3 \mathrm{C})$. This result indicates that ASF inhibits the inflammatory signaling in activated $\mathrm{M} \Phi$ but does not inhibit the $\mathrm{M} \Phi$ differentiation and activation. Therefore, ASF has the potential to improve $\mathrm{M} \Phi$ activity without inflammation. 

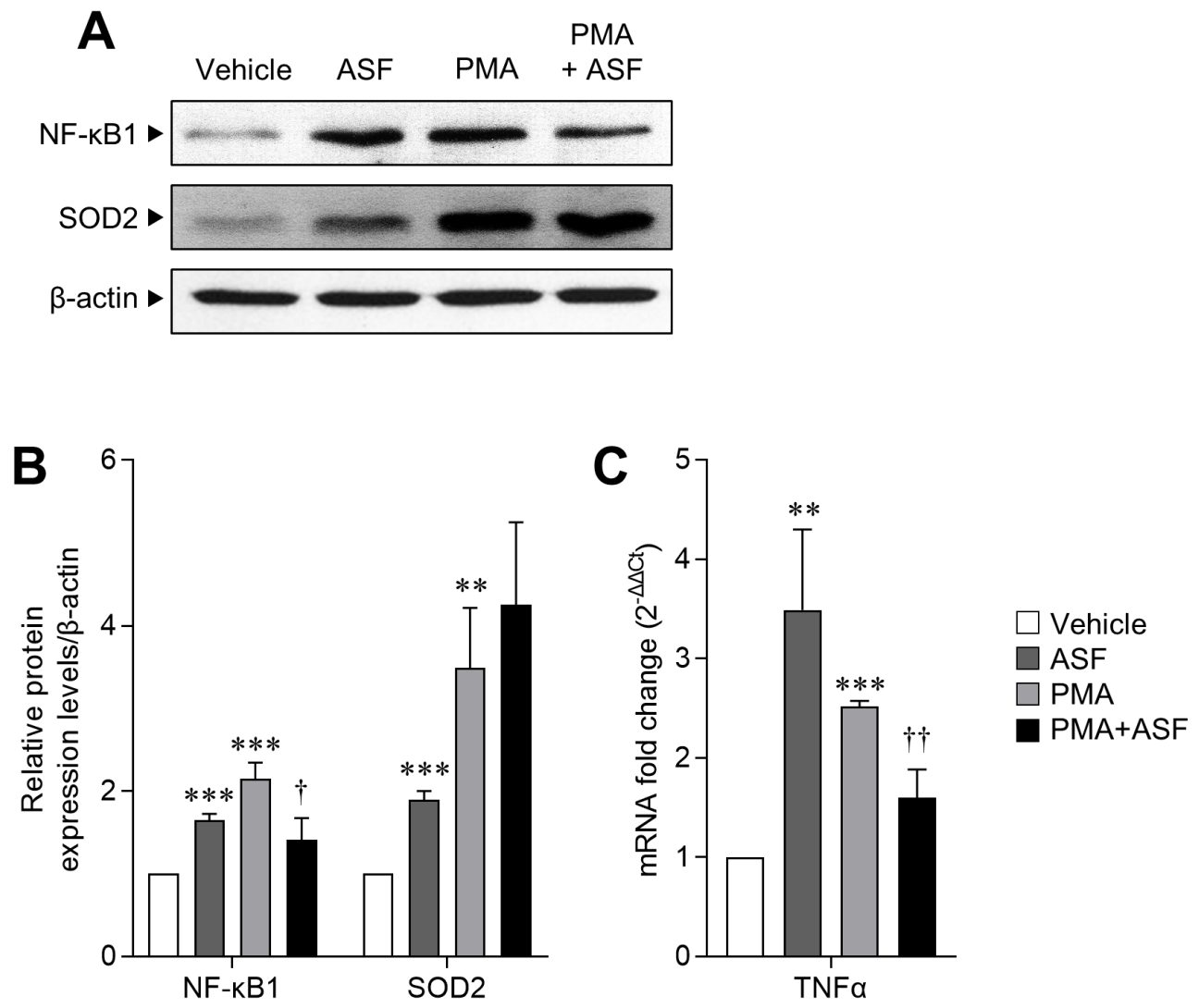

Figure 3. The regulatory effect of ASF on macrophage activation and inflammatory signaling of 3D4/31 MФ. (A) Western blot analyses of NF- $\mathrm{B} 1$, SOD2, and $\beta$-actin of

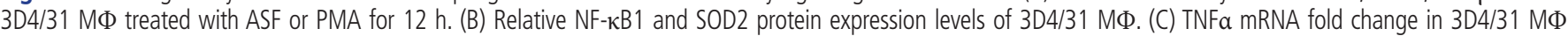
treated with ASF or PMA for 12 h. ASF, Acanthopanax sessiliflorus fruit extract; MФ, macrophage; NF-кB1, nuclear factor kappa B; SOD 2, superoxide dismutase 2; PMA, phorbol 12-myristate 13-acetate; TNFa, tumor necrosis factor $a$. Data represent the mean \pm standard deviation $(n=3) ;{ }^{* *} p<0.01,{ }^{* * *} p<0.001$ vs vehicle; ${ }^{\text {t† }} p<0.01$ vs PMA treated group.

Distinct lipid metabolism-regulatory effects of $A$. sessiliflorus fruit extract in MФ

$M \Phi$ ingest lipoproteins from dying cells by phagocytosis, and eliminate their own intracellular lipids; in addition, infected alveolar MФ reprogram their metabolism to be permissive for FAO thereby upregulating their lipid synthesis and FAO for effective immune response. However, excess lipids in $M \Phi$ result in the formation of foam cells or induce cell death, and FAO is essential for lipid-induced inflammation or lipotoxicity $[13,35]$. Moreover, since TLRs are also capable of recognizing lipoproteins and fatty acid, lipid-induced TLR signaling cascades upregulate the activation and expression of inflammatory genes (NF- $\kappa B, T N F a$, and ILs) [36]. Hence, lipid and FAO balances are important for alveolar $\mathrm{M} \Phi$ activity, survival, and inflammation. In this study, we confirmed that each ASF and PMA treatment upregulated the lipid metabolism, relative to the vehicle. ASF upregulated peroxisome proliferatoractivated receptor alpha (PPARa) and fatty acid synthase (FASN) by up to $224.83 \% \pm 104.39 \%$ and $189.22 \% \pm 87.23 \%$, respectively $(\mathrm{p}<0.05)$, whereas PMA upregulated PPAR $\alpha$ and FASN by up to $156.27 \% \pm 21.41 \%(\mathrm{p}<0.001)$ and $206.68 \%$ $\pm 95.9 \%$, respectively ( $\mathrm{p}<0.05)$. Conversely, ASF-PMA cotreatment reduced PPARa and FASN mRNA expression levels by half in comparison with the PMA treatment (vs PMA, $\mathrm{p}<0.05$, Figure $4 \mathrm{~B}$ ). Accordingly, treatment with ASF and PMA upregulated the lipid contents (oil red $\mathrm{O}$ staining) by $22.64 \% \pm 2.97 \%$ and $20.39 \% \pm 4.76 \%$, respectively, as compared to the vehicle $(\mathrm{p}<0.05)$, and cotreatment of 3D4/31 MФ with ASF-PMA cotreated reduced the lipid content by $11.05 \% \pm 4.39 \%(\mathrm{p}<0.05$, Figure $4 \mathrm{~A})$ as compared to the PMA treated group.

Furthermore, increase in FAO related genes expression was observed after exposure to ASF or PMA, whereas ASF-PMA cotreatment downregulated the FAO genes expression levels. Especially, carnitine palmitoyltransferase 1 (CPT1) is strongly related to FAO and lipid-induced inflammation; CPT1 expression is essential for TLR induced inflammatory signaling that includes NF- $\mathrm{kB}$ and TNF $\alpha$ [35]. In addition, expression levels of Krebs cycle genes were inversely regulated by PMA; i.e., PMA inhibited the expression of 3D4/31 MФ Krebs cycle genes. As expected, ASF-PMA cotreatment resulted in increased expression of Krebs cycle genes by 2 to 4 times, as 
A

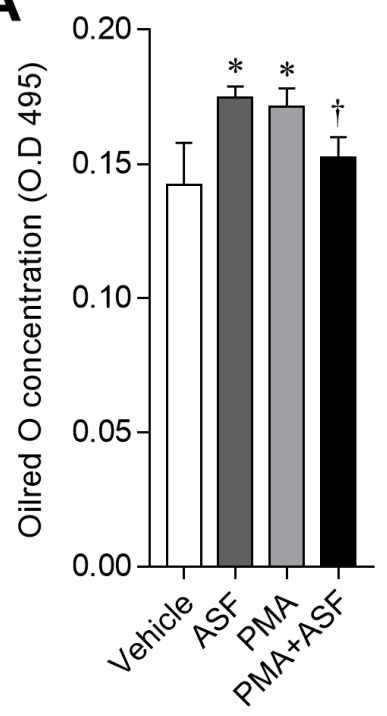

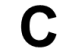

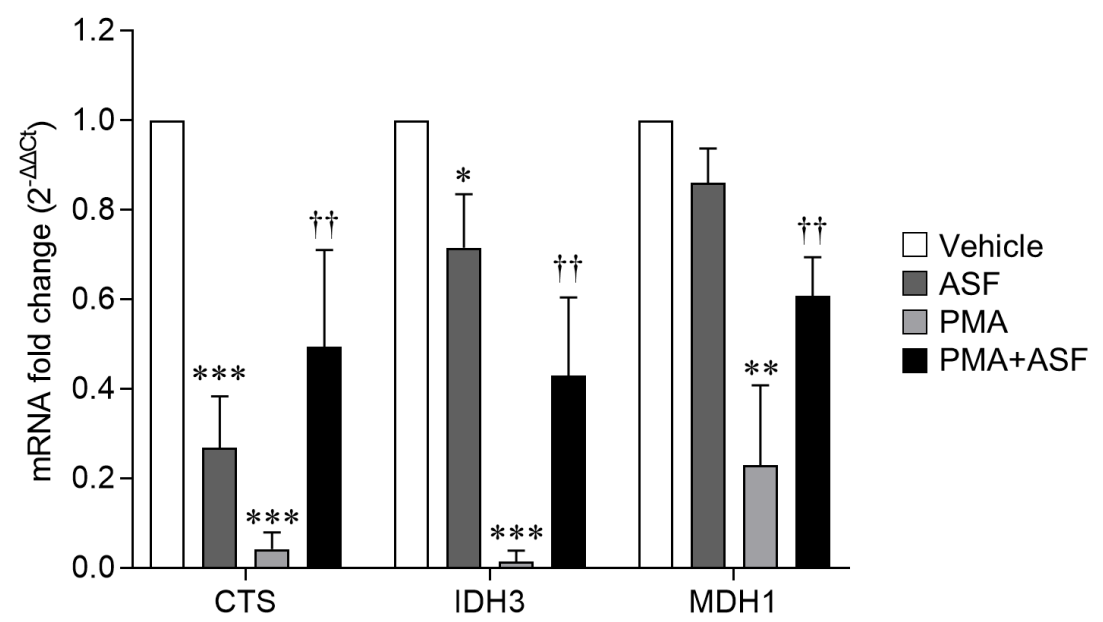

B

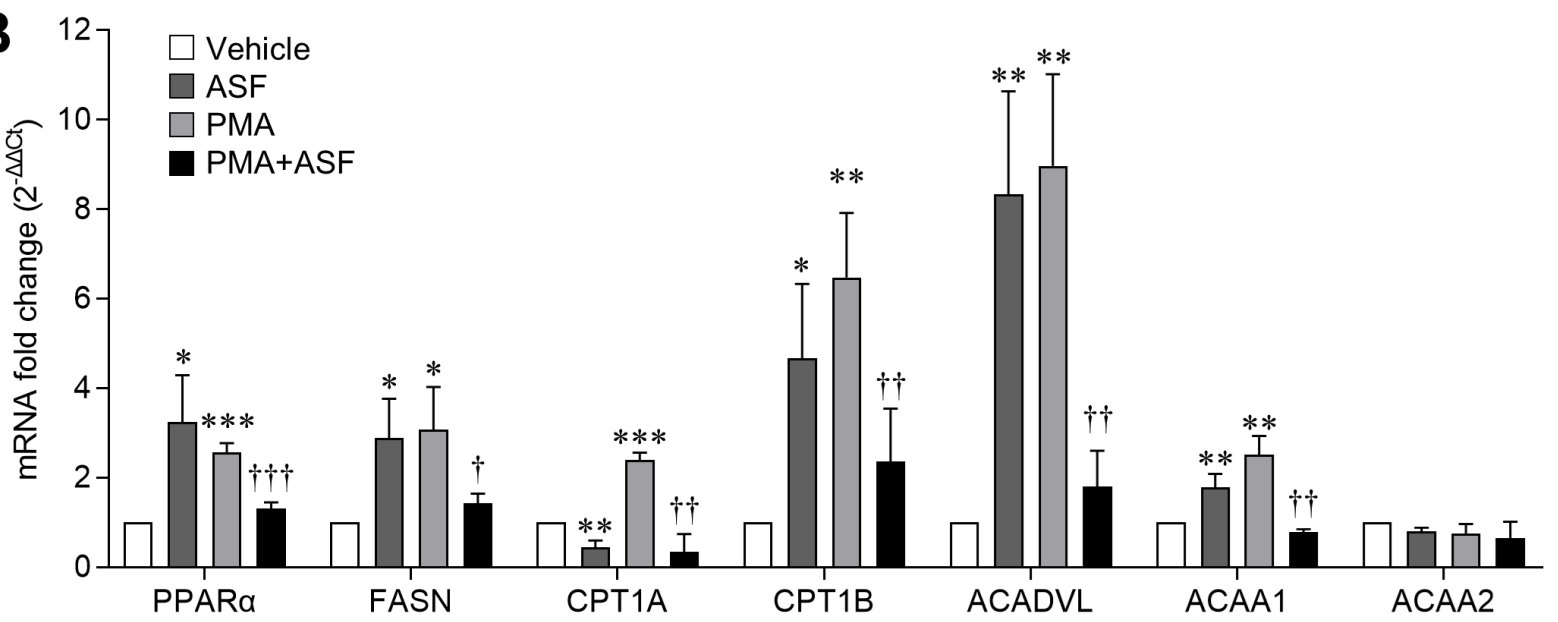

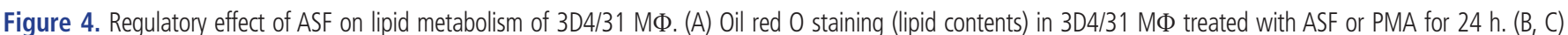
mRNA fold change of lipid synthesis and fatty acid oxidation (B) and Krebs cycle (C) related genes in 3D4/31 MФ treated with ASF or PMA for 12 h. ASF, Acanthopanax sessiliflorus fruit extract; $M \Phi$, macrophage; PMA, phorbol 12-myristate 13-acetate. Data represent the mean $\pm \operatorname{standard}$ deviation $(n=3) ;{ }^{*} p<0.01,{ }^{* *} p<0.01,{ }^{* * *}$ $p<0.001$ vs vehicle; ${ }^{\dagger} p<0.01,{ }^{t \dagger} p<0.01,{ }^{+t \dagger} p<0.01$ vs PMA treated group.

compared to that of the PMA treatment group (Figure 4B, 4C). These lipid metabolism regulations by ASF indicate that ASF does not inhibit the activation of 3D4/31 MФ. Since upregulation of lipid metabolism is essential for initiating $M \Phi$ activation, ASF therefore contributes to MФ activation through lipid metabolism upregulation. However, the lipid metabolism and NF- $\mathrm{KB}$ expression (Figure 3B) of activated 3D4/31 MФ are downregulated after ASF exposure, indicating inhibition of lipid-induced cell death, inflammation, and lipotoxicity.

\section{A. sessiliflorus fruit extract enhances the antibacterial} activity of $\mathrm{M} \Phi$ against $E$. coli $\mathrm{DH} 5$ a

Since phagocytosis is the primary role of $M \Phi$, any infection in the body results in $M \Phi$ activation in an attempt to eliminate the bacteria [37]. We therefore performed an in vitro bacterial killing assay (CFU assay) to examine the effect of ASF on the antibacterial activity of 3D4/31 M $\Phi$ toward E. coli $\mathrm{DH} 5 \mathrm{a}$. We quantified only the ingested E. coli, by washing the activated $M \Phi$ with HBSS and their subsequent disruption. We observed that the ASF-pretreated 3D4/31 MФ resulted in higher mortality of bacteria than the vehicle-pretreated cells. The CFU was similar until $30 \mathrm{~min}$ for both treatment groups. However, $\mathrm{CFU}$ of the vehicle group at $45 \mathrm{~min}$ increased relative to that at $30 \mathrm{~min}$, whereas CFU of the ASF group at $45 \mathrm{~min}$ decreased by $34.48 \% \pm 5.97 \%(\mathrm{p}<0.01)$ relative to the vehicle group (Figure 5A, 5B). After $45 \mathrm{~min}$, an increase was observed in the number of bacterial CFU, indicating loss of phagocytic ability of the 3D4/31, subsequently followed by the imminent death of MФ (total $105 \mathrm{~min}$ incubation) [38,39]. These results indicate that ASF increases the bacterial killing capacity 
A

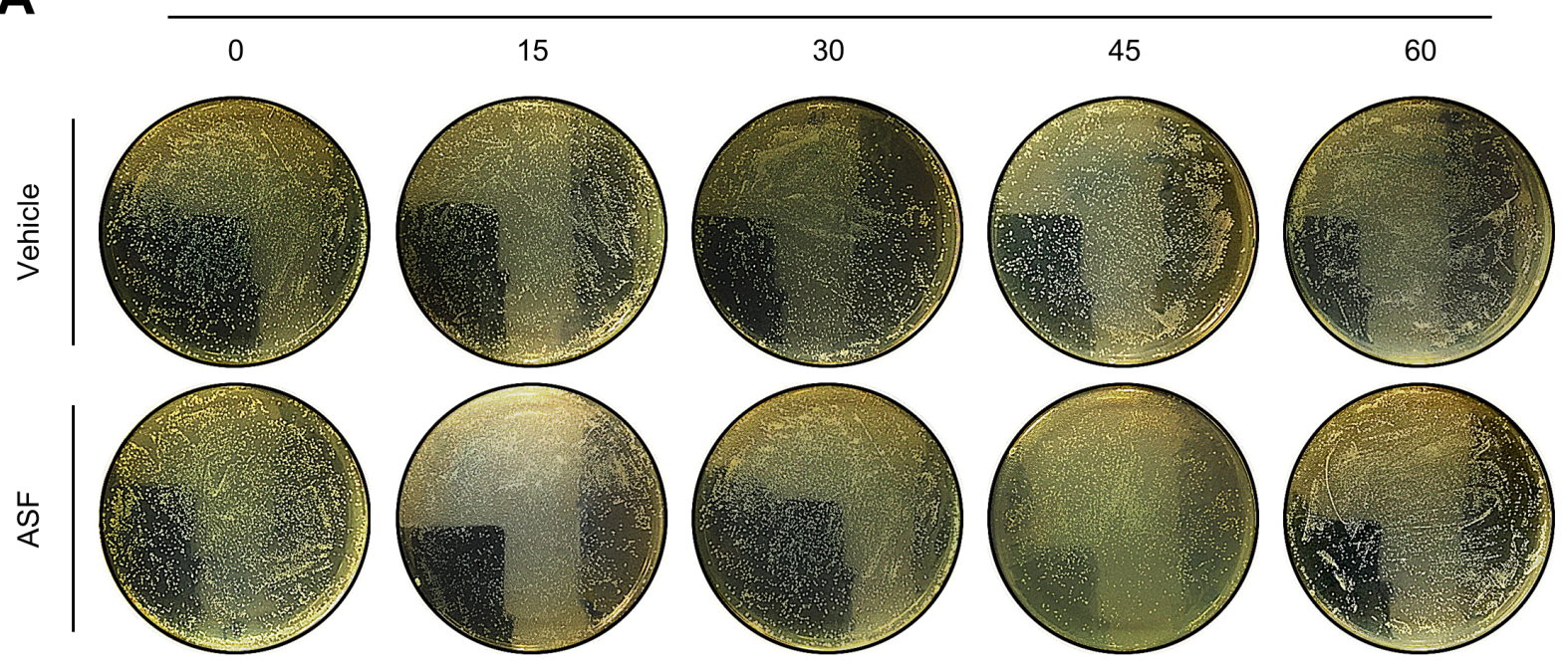

B

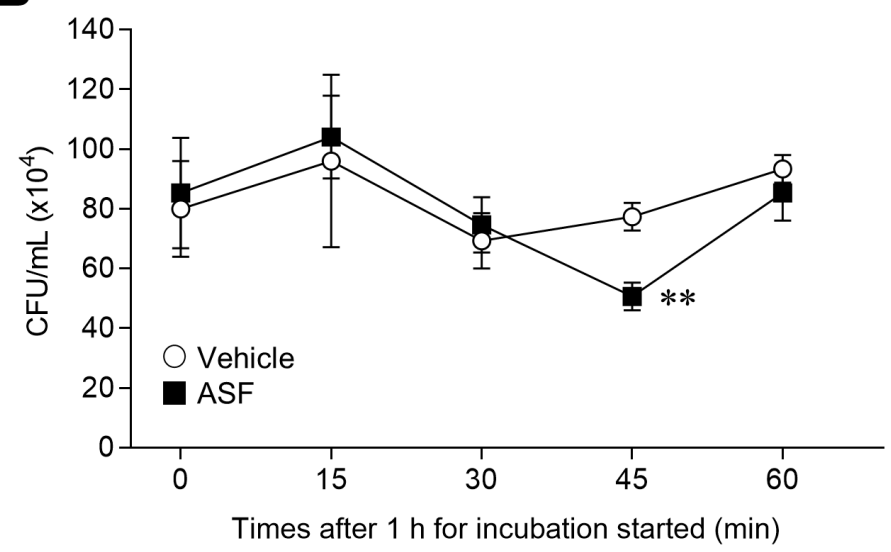

Figure 5. Antibacterial activity of 3D4/31 M $\Phi$ with ASF pretreatment. (A) CFU assay of 3D4/31 M $\Phi$ after ASF pretreatment for $24 \mathrm{~h}$. (B) The CFU assay of ASF-pretreated

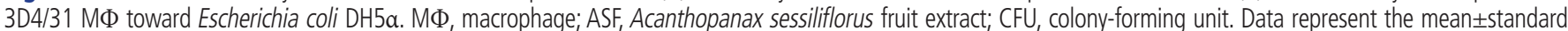
deviation $(n=3) ;{ }^{* *} p<0.01$.

by up to $40 \%$ by upregulating the cell survival rate (Figure 1) and lysosomal activity (Figure 2) in 3D4/31 M.

\section{DISCUSSION}

Respiratory diseases can be caused by infectious microorganisms as well as animal feed conditions, and these diseases have a devastating influence on agricultural workers and porcine health and productivity [40]. A greater problem regarding porcine health is the PRDC, a complex of various disorders and infections of the respiratory system, rather than a disease caused by a single causal infectious agent. PRDC frequently occurs in young pigs between the ages of 15 and 20 weeks, with morbidity as high as $40 \%$ and mortality $20 \%$. Treatment of PRDC is challenging due to the late appearance of symptoms along with growth inhibition, and accompanying various infections [41]. Although antibiotics have been administered to prevent PRDC and promote growth, the recently discovered antibiotic resistance of the main pathogens of PRDC including Streptococcus suis and Actinobacillus pleuropneumoniae have posed challenges to the management of PRDC $[42,43]$. Among the Actinobacillus pleuropneumoniae isolates obtained from porcine farms in Australia, a country free from foot-andmouth disease, $89 \%$ showed erythromycin resistance and $75 \%$ were tetracycline resistant [44]. Because the livestock antibiotics used for preventing infections and promoting growth were discovered to have strengthened the pathogenic bacteria with extended influence on human health, EU has banned the use of growth-promoting antibiotics (GPAs). However, this has resulted in an increased use of therapeutic antibiotics due to the increasing mortality of livestock and the decline in productivity, implying an urgent need to de- 
velop a method to replace GPAs [45]. Recent studies report that the growth-promoting effects of GPAs are induced by suppressed growth of microorganisms in the feed, inhibition of toxic microorganisms in the body of livestock, and enhanced anti-inflammatory activity and feed efficiency [46]. These data directed the focus of research to functional feed additives containing phytogenic materials (phytochemicals) as an alternative to GPA since they originate from natural plants, thereby causing lesser aversion or side effects in both livestock and humans while exerting high anti-inflammatory activity $[47,48]$.

This study was therefore undertaken to examine whether ASF is a potential functional feed additive that could regulate livestock $M \Phi$ function and thereby contribute to reduced antibiotic usage. Our findings confirm that ASF significantly improves the antimicrobial activity and survival rate of $M \Phi$ by regulating the lysosomal activity, NF- $\kappa \mathrm{B}$ expression, and lipid metabolism of porcine alveolar 3D4/31 M $\Phi$. Besides the anti-inflammatory effect based on the reduced expression of proinflammatory cytokines $[49,50]$, NF- $\kappa B$ inhibition suppresses the activity of TLR4 induced by lipopolysaccharide and phagocytosis of $E$. coli, given that NF- $\mathrm{kB}$ is an essential factor for $M \Phi$ activation [51]. Furthermore, $M \Phi$ activation results in reduced production of mitochondrial adenosine triphosphate (ATP) after the production of mROS [31], while increased lipid metabolism facilitates the absorption and synthesis of lipids, and PPAR $\alpha$ promotes $\beta$-oxidation that utilizes fatty acids to produce ATP [52]. However, excessive intracellular accumulation of lipids that goes beyond $\mathrm{M} \Phi$ functional capacity induces apoptosis [13]. Thus, NF- $\mathrm{kB}$ and lipid metabolism is a two-edged sword for MФ activity and survival, and we found that ASF is able to regulate them effectively, such that it enhances the innate immune response during inactivation and inhibits inflammation and apoptosis upon activation by PMA. These effects of ASF suggest that a shift should be made from the conventional method of unconditionally inhibiting the regulatory factors of inflammation, such as NF- $\kappa B$ and TNFa in $M \Phi$, to the use of independent methods of regulating NF- $\mathrm{kB}$ and lipid metabolism for the purpose of preventing infections and for post-infection treatment. The confirmed antimicrobial and anti-inflammatory activities of ASF and the findings of this study that demonstrate the alleviating effects of ASF on the porcine $M \Phi$ function and health, validates the high potential of ASF as a functional feed additive that can replace GPA. This study confirms that exposure to ASF enhances the porcine macrophage function. However, in addition to E. coli, there is a requirement to experiment with disease-causing bacteria that actually infect porcine (including PRDC related bacteria), and furthermore, in vivo testing is necessary to verify the efficacy of ASF in improving immunity, in small animal models such as mice. These extensive studies will help to further review and confirm the applicability of ASF to livestock, and enhance the possibility of development as an alternative to GPA and a functional feed additive.

\section{CONFLICT OF INTEREST}

We certify that there is no conflict of interest with any financial organization regarding the material discussed in the manuscript.

\section{ACKNOWLEDGMENTS}

This work was supported by the Next-Generation BioGreen 21 Program (rojects No. PJ01315101 and PJ01323005) of the Rural Development Administration, Republic of Korea.

\section{REFERENCES}

1. Sherman RA. Maggot therapy takes us back to the future of wound care: new and improved maggot therapy for the 21st century. J Diabetes Sci Technol 2009;3:336-44. https://doi. org/10.1177/193229680900300215

2. Davies J, Davies D. Origins and evolution of antibiotic resistance. Microbiol Mol Biol Rev 2010;74:417-33. https://doi. org/10.1128/MMBR.00016-10

3. Ventola CL. The antibiotic resistance crisis: part 1: causes and threats. P T 2015;40:277-83.

4. Spellberg B, Gilbert DN. The future of antibiotics and resistance: a tribute to a career of leadership by John Bartlett. Clin Infect Dis 2014;59(Suppl 2):S71-5. https://doi.org/10.1093/cid/ciu392

5. Cully M. Public health: the politics of antibiotics. Nature 2014; 509:S16-7. https://doi.org/10.1038/509S16a

6. Thacker EL. Immunology of the porcine respiratory disease complex. Vet Clin North Am Food Anim Pract 2001;17:55165. https://doi.org/10.1016/S0749-0720(15)30006-2

7. Bianco C, Griffin FM, Jr., Silverstein SC. Studies of the macrophage complement receptor. Alteration of receptor function upon macrophage activation. J Exp Med 1975;141:1278-90. https://doi.org/10.1084/jem.141.6.1278

8. Tak PP, Firestein GS. NF-kappaB: a key role in inflammatory diseases. J Clin Invest 2001;107:7-11. https://doi.org/10.1172/ JCI11830

9. Ecker J, Liebisch G, Englmaier M, Grandl M, Robenek H, Schmitz G. Induction of fatty acid synthesis is a key requirement for phagocytic differentiation of human monocytes. Proc Natl Acad Sci USA 2010;107:7817-22. https://doi.org/ 10.1073/pnas.0912059107

10. Huang L, Nazarova EV, Tan S, Liu Y, Russell DG. Growth of Mycobacterium tuberculosis in vivo segregates with host macrophage metabolism and ontogeny. J Exp Med 2018;215:113552. https://doi.org/10.1084/jem.20172020

11. Forman HJ, Torres M. Redox signaling in macrophages. Mol 
Aspects Med 2001;22:189-216. https://doi.org/10.1016/S00982997(01)00010-3

12.Xaus J, Cardo M, Valledor AF, Soler C, Lloberas J, Celada A. Interferon gamma induces the expression of $\mathrm{p} 21^{\text {waf-1 }}$ and arrests macrophage cell cycle, preventing induction of apoptosis. Immunity 1999;11:103-13. https://doi.org/10.1016/S10747613(00)80085-0

13.Devries-Seimon T, Li Y, Yao PM, et al. Cholesterol-induced macrophage apoptosis requires ER stress pathways and engagement of the type A scavenger receptor. J Cell Biol 2005;171: 61-73. https://doi.org/10.1083/jcb.200502078

14.Lee SH, Lee YS, Jung SH, et al. Antitumor and immunostimulating activities of Acanthopanax sessiliflorus fruits. Nat Prod Sci 2003;9:112-6.

15. Yang S, Chun-Juan Y, Kai Y, Fa-Mei L. In vivo antithrombotic and antiplatelet activities of a quantified Acanthopanax sessiliflorus fruit extract. Chin J Nat Med 2011;9:141-5. https://doi.org/ 10.3724/SP.J.1009.2011.00141

16. Kim SJ, Hwang E, Yi SS, et al. Sea buckthorn leaf extract inhibits glioma cell growth by reducing reactive oxygen species and promoting apoptosis. Appl Biochem Biotechnol 2017;182: 1663-74. https://doi.org/10.1007/s12010-017-2425-4

17. Hwang E, Sim S, Park SH, et al. Anti-proliferative effect of Zea mays L. cob extract on rat C6 glioma cells through regulation of glycolysis, mitochondrial ROS, and apoptosis. Biomed Pharmacother 2018;98:726-32. https://doi.org/10.1016/j.biopha. 2017.12.115

18. Bourgaud F, Gravot A, Milesi S, Gontier E. Production of plant secondary metabolites: a historical perspective. Plant Sci 2001; 161:839-51. https://doi.org/10.1016/S0168-9452(01)00490-3

19. Rice-Evans CA, Miller NJ, Bolwell PG, Bramley PM, Pridham JB. The relative antioxidant activities of plant-derived polyphenolic flavonoids. Free Radic Res 1995;22:375-83.

20. Quideau S, Deffieux D, Douat-Casassus C, Pouysegu L. Plant polyphenols: chemical properties, biological activities, and synthesis. Angew Chem Int Ed Engl 2011;50:586-621. https:// doi.org/10.1002/anie.201000044

21. Monobe M, Ema K, Tokuda Y, Maeda-Yamamoto M. Enhancement of phagocytic activity of macrophage-like cells by pyrogallol-type green tea polyphenols through caspase signaling pathways. Cytotechnology 2010;62:201-3. https://doi. org/10.1007/s10616-010-9280-2

22.Perva-Uzunalic A, Skerget M, Knez Z, Weinreich B, Otto F, Gruner S. Extraction of active ingredients from green tea (Camellia sinensis): Extraction efficiency of major catechins and caffeine. Food Chem 2006;96:597-605. https://doi.org/10. 1016/j.foodchem.2005.03.015

23. Kim JS. Investigation of phenolic, flavonoid, and vitamin contents in different parts of Korean ginseng (Panax ginseng C.A. Meyer). Prev Nutr Food Sci 2016;21:263-70. https://doi.org/ 10.3746/pnf.2016.21.3.263

24.Vadiveloo PK. Macrophages--proliferation, activation, and cell cycle proteins. J Leukoc Biol 1999;66:579-82. https://doi. org/10.1002/jlb.66.4.579

25. Vistica DT, Skehan P, Scudiero D, Monks A, Pittman A, Boyd MR. Tetrazolium-based assays for cellular viability: a critical examination of selected parameters affecting formazan production. Cancer Res 1991;51:2515-20.

26. Dey A, Li W. Cell cycle-independent induction of D1 and D2 cyclin expression, but not cyclin-Cdk complex formation or $\mathrm{Rb}$ phosphorylation, by IFNgamma in macrophages. Biochim Biophys Acta 2000;1497:135-47. https://doi.org/10.1016/S01674889(00)00053-7

27. Gordon S. Phagocytosis: an immunobiologic process. Immunity 2016;44:463-75. https://doi.org/10.1016/j.immuni.2016. 02.026

28. Dupre-Crochet S, Erard M, Nubetae O. ROS production in phagocytes: why, when, and where? J Leukoc Biol 2013;94: 657-70. https://doi.org/10.1189/jlb.1012544

29. Apel K, Hirt H. Reactive oxygen species: metabolism, oxidative stress, and signal transduction. Annu Rev Plant Biol 2004;55: 373-99. https://doi.org/10.1146/annurev.arplant.55.031903. 141701

30. Pandey KB, Rizvi SI. Plant polyphenols as dietary antioxidants in human health and disease. Oxid Med Cell Longev 2009;2:270-8. http://dx.doi.org/10.4161/oxim.2.5.9498

31. West AP, Brodsky IE, Rahner C, et al. TLR signalling augments macrophage bactericidal activity through mitochondrial ROS. Nature 2011;472:476-80. https://doi.org/10.1038/nature09973

32.Sheng Y, Abreu IA, Cabelli DE, et al. Superoxide dismutases and superoxide reductases. Chem Rev 2014;114:3854-918. https://doi.org/10.1021/cr4005296

33.Zelko IN, Mariani TJ, Folz RJ. Superoxide dismutase multigene family: a comparison of the CuZn-SOD (SOD1), Mn-SOD (SOD2), and EC-SOD (SOD3) gene structures, evolution, and expression. Free Radic Biol Med 2002;33:337-49. https:// doi.org/10.1016/S0891-5849(02)00905-X

34. Schutze S, Wiegmann K, Machleidt T, Kronke M. TNF-induced activation of NF-kappa B. Immunobiology 1995;193:193-203. https://doi.org/10.1016/S0171-2985(11)80543-7

35. Warfel JD, Bermudez EM, Mendoza TM, et al. Mitochondrial fat oxidation is essential for lipid-induced inflammation in skeletal muscle in mice. Sci Rep 2016;6:37941. https://doi. org/10.1038/srep37941

36. Tornatore L, Thotakura AK, Bennett J, Moretti M, Franzoso G. The nuclear factor kappa B signaling pathway: integrating metabolism with inflammation. Trends Cell Biol 2012;22:55766. https://doi.org/10.1016/j.tcb.2012.08.001

37. Cole J, Aberdein J, Jubrail J, Dockrell DH. The role of macrophages in the innate immune response to Streptococcus pneumoniae and Staphylococcus aureus: mechanisms and contrasts. Adv Microb Physiol 2014;65:125-202. https:/doi.org/10.1016/ bs.ampbs.2014.08.004

38. Chiang C-Y, Ulrich RL, Ulrich MP, et al. Characterization of 
the murine macrophage response to infection with virulent and avirulent Burkholderia species. BMC Microbiol 2015;15: 259. https://doi.org/10.1186/s12866-015-0593-3

39. Baldwin CL, Goenka R. Host immune responses to the intracellular bacteria Brucella: does the bacteria instruct the host to facilitate chronic infection? Crit Rev Immunol 2006;26: 407-42.

40. Linaker C, Smedley J. Respiratory illness in agricultural workers. Occup Med (Lond) 2002;52:451-9.

41. Hansen MS, Pors SE, Jensen HE, et al. An investigation of the pathology and pathogens associated with porcine respiratory disease complex in Denmark. J Comp Pathol 2010;143:12031. https://doi.org/10.1016/j.jcpa.2010.01.012

42.Levesque C, Provost C, Labrie J, et al. Actinobacillus pleuropneumoniae possesses an antiviral activity against porcine reproductive and respiratory syndrome virus. PLoS One 2014;9:e98434. https://doi.org/10.1371/journal.pone.0098434

43. Aarestrup FM, Oliver Duran C, Burch DG. Antimicrobial resistance in swine production. Anim Health Res Rev 2008; 9:135-48. https://doi.org/10.1017/S1466252308001503

44.Dayao DA, Gibson JS, Blackall PJ, Turni C. Antimicrobial resistance in bacteria associated with porcine respiratory disease in Australia. Vet Microbiol 2014;171:232-5. https:// doi.org/10.1016/j.vetmic.2014.03.014

45. Casewell M, Friis C, Marco E, McMullin P, Phillips I. The European ban on growth-promoting antibiotics and emerging consequences for human and animal health. J Antimicrob Chemother 2003;52:159-61. https://doi.org/10.1093/jac/ dkg313

46. Chattopadhyay MK. Use of antibiotics as feed additives: a burning question. Front Microbiol 2014;5:334. https://doi. org/10.3389/fmicb.2014.00334

47.Lillehoj HS, Lee KW. Immune modulation of innate immunity as alternatives-to-antibiotics strategies to mitigate the use of drugs in poultry production. Poult Sci 2012;91:1286-91. https:// doi.org/10.3382/ps.2012-02374

48. Gasparrini M, Forbes-Hernandez TY, Giampieri F, et al. Antiinflammatory effect of strawberry extract against LPS-induced stress in RAW 264.7 macrophages. Food Chem Toxicol 2017; 102:1-10. https://doi.org/10.1016/j.fct.2017.01.018

49. Juliana C, Fernandes-Alnemri T, Wu J, et al. Anti-inflammatory compounds parthenolide and Bay 11-7082 are direct inhibitors of the inflammasome. J Biol Chem 2010;285:9792-802. https:// doi.org/10.1074/jbc.M109.082305

50.Chen SJ, Huang WC, Yang TT, Lu JH, Chuang LT. Incorporation of sciadonic acid into cellular phospholipids reduces pro-inflammatory mediators in murine macrophages through NF-kappa B and MAPK signaling pathways. Food Chem Toxicol 2012;50:3687-95. https://doi.org/10.1016/j.fct.2012. 07.057

51.Suzuki E, Umezawa K. Inhibition of macrophage activation and phagocytosis by a novel NF-kappaB inhibitor, dehydroxymethylepoxyquinomicin. Biomed Pharmacother 2006;60: 578-86. https://doi.org/10.1016/j.biopha.2006.07.089

52. Minnich A, Tian N, Byan L, Bilder G. A potent PPARalpha agonist stimulates mitochondrial fatty acid beta-oxidation in liver and skeletal muscle. Am J Physiol Endocrinol Metab 2001;280:E270-9. https://doi.org/10.1152/ajpendo.2001.280. 2.E270 